\title{
ZAKAT DAN PAJAK SERTA REGULASINYA DI INDONESIA
}

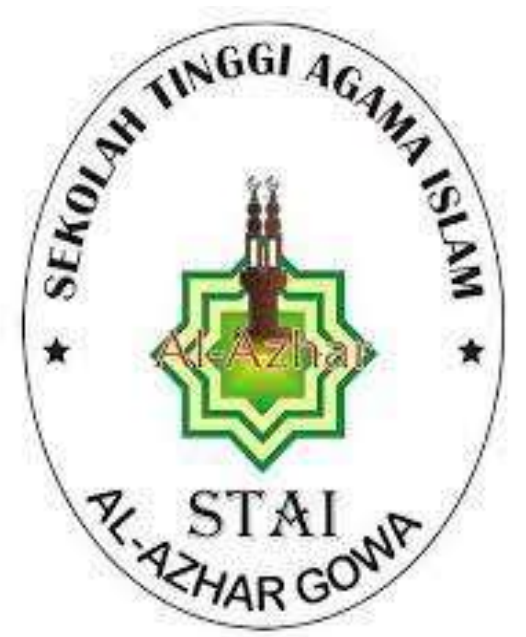

Makalah Diajukan untuk memenuhi tugas mata kuliah

fikih zakat dan wakaf

Oleh :

Masni

Nurhalisa Hasanuddin

Dosen :

Samsul Arifai, S.A.B., M.A.

\section{EKONOMI SYARIAH \\ STAI AL-AZHAR GOWA}

2021 


\section{DAFTAR ISI}

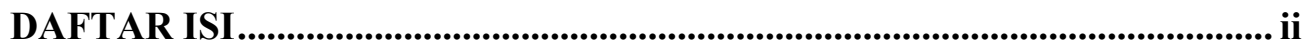

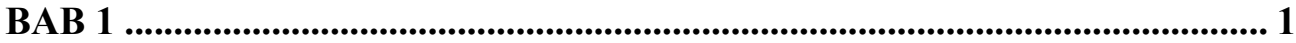

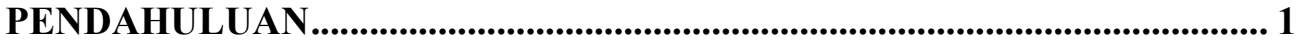

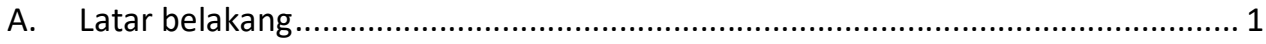

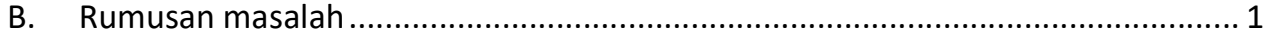

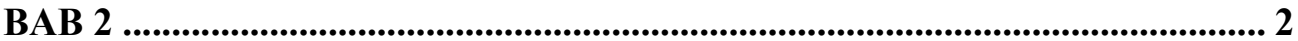

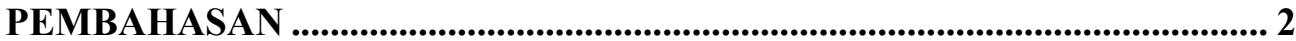

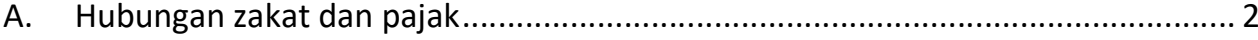

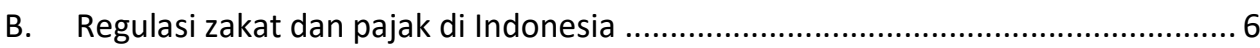

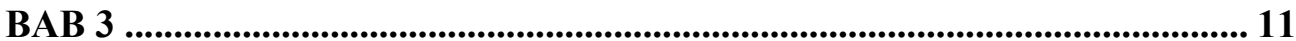

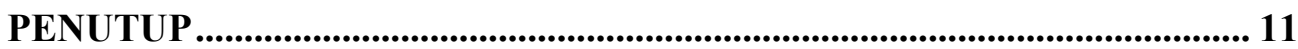

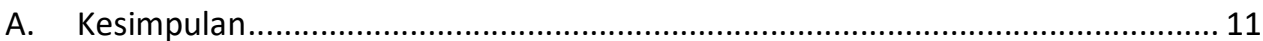

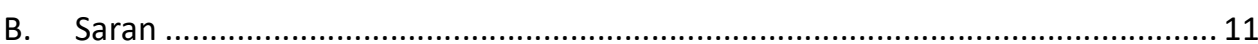

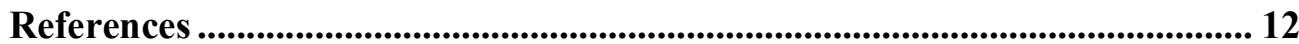




\section{BAB 1 \\ PENDAHULUAN}

A. Latar belakang

Zakat adalah salah satu tiang pokok ajaran islam yang harus ditegakkan ditengah-tengah kehidupan kaum muslimin dari empat tiang pokok lainnya yakni syahadat, shalat, puasa dan haji. Sedangkan Pajak merupakan salah satu sumber pendapatan negara.

Pemungutan pajak digunakan untuk membiayai semua pengeluaran yang dikeluarkan negara guna mewujudkan pembangunan nasional. Proyek pembangunan yang dilaksanakan oleh pemerintah digunakan untuk kepentingan bersama yang dibangun dengan mengunakan dana pajak yang telah dikumpulkan dari masyarakat. Dengan adanya pajak, masyarakat pun akan merasakan hasilnya . masyarakat bisa menikmati dan memanfatkan sarana dan prasarana umum yang tersedia seperti sarana tranportasi, pendidikan, kesehatan, komunikasi, keamanan, hukum, sarana kegiatan lainnya yang mendukung kegiatan sehari-hari

Zakat dan Pajak meski kedua sama-sama merupakan kewajiban dalam bidang harta, namun keduanya berbeda sifatnya, berbeda sumbernya, sasaran, kadarnya dan berbeda pula mengenai tujuannya dan jaminanya. Pajak dan zakat yang tidak dapat dipisahkan dalam kegiatan pemenuhan kewajiban baik dalam kehidupan beragama maupun bernegara.

\section{B. Rumusan masalah}

1. Apa hubungan zakat dan pajak?

2. Regulasi zakat dan pajak di Indonesia. 


\section{BAB 2 \\ PEMBAHASAN}

\section{A. Hubungan zakat dan pajak}

\section{Pengertian Pajak}

Pajak adalah iuran rakyat kepada negara berdasarkan undang-undang sehingga dapat dipaksakan dan tidak mendapat balas jasa secara langsung. Pajak dipungut berdasarkan normanorma hukum untuk menutup biaya produksi barang dan jasa kolektif untuk mencapai kesejahteraan umum. Penolakan, penghindaran, atau perlawanan terhadap pajak pada umumnya termasuk pelanggaran hukum.

Menurut Pasal 1 angka 1 UU No. 6 Tahun 1983, sebagaimana telah disempurnakan dalam UU No. 28 tahun 2007 tentang Ketentuan Umum dan Tata Cara Perpajakan, pajak adalah kontribusi wajib kepada negara yang terutang oleh pribadi atau badan yang bersifat memaksa berdasarkan undang-undang, dengan tidak mendapatkan timbal balik secara langsung dan digunakan untuk keperluan negara bagi sebesarbesarnya kemakmuran rakyat.

2. Perbedaan zakat dan pajak

Mengutip dari buku Masail Fiqhiyah karya M. Ali Hasan, berikut adalah perbedaan zakat dan pajak:

1. Zakat mengandung arti suci, tambah, dan berkah. Orang yang mengeluarkan zakat, jiwanya bersih dari sifat kikir, tamak, hartanya tidak kotor lagi karena hak orang lain telah disisihkan dan diberikan kepada yang berhak menerimanya. Berkurang dalam pandangan manusia, bertambah dalam pandangan agama (Allah). Sementara pajak adalah utang, pajak tanah, upeti, dan sebagainya yang wajib dibayar sehingga pajak terkesan beban berat yang dipaksakan walaupun hasil pajak juga dimanfaatkan untuk pembangunan dan kepentingan negara. 
Berbeda dengan zakat, ada dorongan yang membuat orang tidak keberatan mengeluarkan zakat, seperti firman Allah:

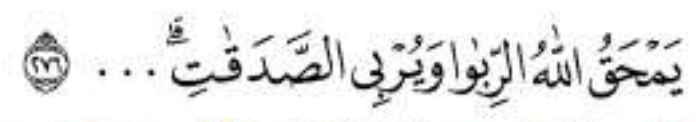

"Allah memusnahkan riba dan menyuburkan sedehah..."(QS. Al-Barqarah [2]: 276).

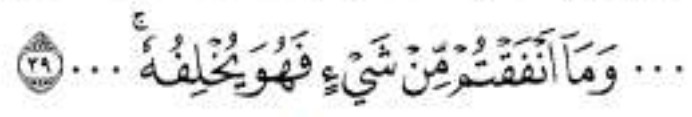

"...Dan barang apa saja yang kamu nafkahkan, maka Allah akan menggantinya..." (QS. Saba' [34]: 39)

2. Zakat adalah ibadah yang diwajibkan kepada umat sebagai tanda bersyukur kepada Allah dan mendekatkan diri kepada-Nya, sedangkan pajak adalah kewajiban atas warga negara, baik muslim maupun nonmuslim, yang tidak dikaitkan dengan ibadah. Zakat harus diniatkan untuk mengeluarkannya, sedangkan pajak tidak memerlukan niat.

3. Zakat ketentuannya dari Allah dan Rasul-Nya, yaitu penentuan nisabnya dan penyalurannya. Pajak ketentuannya sangat bergantung pada kebijaksanaan penguasa (pemerintah). Orang yang dikenakan pajak belum tentu harus membayar zakat karena zakat ada patokan nisabnya dansudah baku. Pajak ketentuannya ditetapkan oleh pemerintah (penguasa). Pada suatu waktu, pajak bisa dimunculkan dan pada waktu yang lain mungkin dihapuskan.

4. Zakat adalah kewajiban yang bersifat permanen, terus-menerus, berjalan selama hidup di dunia. Kewajiban mengeluarkan zakat tidak bisa dihapuskan oleh siapa pun, sedangkan pajak bisa ditambah, dikurangi, bahkan dihapuskan sesuai dengan kepentingan agama.

5. Pos-pos penyaluran zakat sudah dijelaskan dalam Al-Quran dan kemudian diikuti oleh amal perbuatan Rasulullah serta para sahabat. Pengeluarannya lebih terbatas bila dibandingkan dengan pajak yang cakupannya lebih umum. 6. Wajib pajak berhubungan dengan pemerintah (penguasa) dan adakalanya orang menghindar dari kewajiban membayar pajak, kecuali orang yang benar-benar sadar sebagai warga negara yang baik. Berbeda 
dengan pajak, orang yang wajib zakat langsung berhubungan dengan Allah, maksudnya tidak bisa disembunyikan. Muzakki berharap agar zakatnya diterima oleh Allah dan mengharapkan rida-Nya.

6. Maksud dan tujuan zakat mengandung pembinaan spiritual dan moral yang lebih tinggi dari maksud serta tujuan pajak. Asas tempat berpijak zakat dan pajak jauh berbeda. Zakat asasnya firman Allah, sedangkan pajak hasil rumusan manusia berdasarkan kebijaksanaan yang sewaktuwaktu bisa berubah.

Sementara itu, menurut Yusuf Qardhawi, dalam bukunya Hukum Zakat, perbedaan zakat dan pajak, antara lain:

1. Dari segi nama dan etika Keduanya memberikan motivasi yang berbeda. Secara etimologis, zakat berarti bersih, suci, tumbuh, berkah, maslahat, dan berkembang. Artinya, setiap harta yang dikeluarkan zakatnya akan bersih, tumbuh, dan berkah. Sementara itu, pajak berasal dari kata al-dharibah, yang secara etimologis berarti beban (upeti).

2. Dari segi hakikat dan tujuan Zakat dikaitkan dengan masalah ibadah dalam rangka mendekatkan diri kepada Allah, sedangkan pajak dikaitkan dengan kepatuhan pada peraturan negara.

3. Dari segi batas minimal dan ketentuannya Zakat memiliki nisab dan persentase yang sifatnya baku, yang tidak bisa dikurangi atau ditambahtambahi oleh siapa pun, berdasarkan ketentuan yang tertuang dalam berbagai hadis. Sementara pajak, aturan besar dan pemungutannya bisa berubah-ubah sesuai jenis, sifat, dan cirinya serta kebijakan pemerintah.

4. Dari segi kelestarian dan kelangsungannya Zakat bersifat tetap dan terusmenerus, sedangkan pajak berubah-ubah.

5. Dari segi penggunaan Sasaran zakat telah terang dan jelas, yaitu digunakan untuk kepentingan mustahiq yang berjumlah 8 ashnaf, sedangkan pajak dapat digunakan dalam seluruh sektor kehidupan (pengeluaran umum negara) walaupun dianggap tidak berkaitan dengan ajaran agama.

6. Dari segi hubungan dengan penguasa Hubungan wajib pajak sangat erat dan bergantung pada penguasa. Wajib zakat berhubungan dengan 
Tuhannya. Bila penguasa tidak berperan, individu bisa mengeluarkannya sendiri-sendiri.

7. Segi maksud dan tujuan Zakat memiliki tujuan spiritual dan moral yang lebih tinggi daripada pajak.

Berdasarkan poin-poin tersebut, dapat dikatakan bahwa zakat adalah ibadah dan pajak sekaligus. Sebagai pajak, zakat merupakan kewajiban berupa harta yang pengurusannya dilakukan oleh negara. Bila seseorang tidak mau membayarnya secara sukarela, negara memintanya secara paksa, kemudian hasilnya digunakan untuk membiayai proyek-proyek untuk kepentingan masyarakat. Dalam menyikapi perbedaan antara zakat dan pajak, keduanya merupakan suatu yang telah ditetapkan, baik oleh pemerintah maupun agama, yang wajib kita patuhi.

3. Pendapat Para Ulama mengenai zakat dan pajak

Berikut adalah beberapa pendapat dari para ulama mengenai zakat dan pajak, antara lain:

a. Syekh Ulaith Syekh Ulaith, dalam fatwanya dari mazhab Maliki, menyebutkan bahwa seseorang yang memiliki ternak yang sudah mencapai nisabnya dan dipungut uang setiap tahunnya, tetapi tidak atas nama zakat, ia tidak boleh berniat zakat. Jika ia berniat zakat, kewajibannya tidak menjadi gugur, sebagaimana telah difatwakan oleh Natsir al-Hatab.

b. Rasyid Ridha Seseorang yang mempunyai tanah dan telah dipungut uangnya separuh dan seperempat oleh orang nasrani tidaklah termasuk kewajibab zakat karena sesungguhnya dari hasil bumi itu adalah dari harta zakat yang wajib dikeluarkan pada delapan sasaran (delapan ashnaf) menurut nash. Maka bebaslah pemilik tanah dari kewajibanya. Harta yang dipungut orang nasrani dianggap sebagai pajak dan tidak menggugurkan wajib zakat. Hal ini berarti bahwa pajak tidak dapat dianggap sebagai zakat.

c. Syekh Mahmud Syaltut Zakat bukanlah pajak. Pada prinsipnya, pendapat beliau sama dengan ulama-ulama yang mengatakan bahwa zakat dan pajak berbeda asas serta sasarannya. Zakat kewajiban kepada Allah, sedangkan pajak kewajiban kepada pemerintah (penguasa). 
d. Syekh Abu Zahrah Pajak sampai sekarang tidak memiliki nilai-nilai khusus yang dapat memberikan jaminan sosial, padahal tujuan pokok pajak adalah menanggulangi masalah sosial kemasyarakatan.

Dari keempat pendapat ulama tersebut, dapat dipahami bahwa zakat harus dikeluarkan sesudah memenuhi persyaratan, walaupun seseorang telah membayar pajak. Sebaliknya, pajak boleh dipungut bila diperlukan, walaupun zakat sudah ditunaikan.

\section{B. Regulasi zakat dan pajak di Indonesia}

Regulasi tentang zakat berdasarkan UU No. 23 Tahun 2011 tentang Pengelolaan zakat mengisyaratkan bahwa pembayaran zakat khususnya zakat profesi berkaitan erat dengan pengurangan pembayaran pajak yang ada di Negara Indonesia, namun dalam kenyataannya masih banyak ditemukan kejanggalan dan ketidaksinkronan dimana regulasi tersebut belum berjalan secara optimal.

Zakat di beberapa Negara dapat berguna untuk mengurangi jumlah pembayaran pajak profesi yang ada sehingga rakyat merasa terbantu dengan regulasi tersebut, akan tetapi di Negara Indonesia beberapa daerah sudah mencoba menerapakan hal tersebut akan tetapi dalam prakteknya ditemukan bahwa para muzakki double payment dimana mereka disamping membayar zakat mereka juga membayar pajak, sehingga hal ini tentunya regulasi tersebut belum berjalan dengan baik.

Ada beberapa temuan ketidaksinkronan pembayaran zakat yang diharapkan dapat mengurangi pembayaran pajak, diantaranya adalah yang pertama, payung hukumnya yang belum baku sehingga kelegalitasannya masih dipertanyakan, kedua, belum adanya kerjasama yang intens antara lembaga yang menangani zakat dan lembaga yang menangani pajak dalam hal teknis dan administrative dan terakhir yang ketiga adalah perlu adanya sosialisasi yang intens ke pada khalayak ramai bahwa salah satu kewajiban seorang muslim dan warga yang baik adalah disamping membayar zakat juga membayar pajak. Penguatan regulasi zakat dan pajak diharapak dapat meningkatkan pembayaran zakat secara optimal dan tentunya diharapkan akan mengoptimalkan pula penerimaan pajak untuk Negara Indonesia. 
Undang-Undang Nomor 23 Tahun 2011 Tentang Pengelolaan zakat, maka masyarakat diberikan sarana hukum untuk menunaikan kewajiban yang bersumber dari agama kepada lembaga-lembaga tertentu. Secara subtansi, adanya regulasi terhadap ketentuan Undang-Undang Nomor 23 Tahun 2011 Tentang Pengelolaan Zakat, menunjukkan sebuah keinginan negara untuk mengatur warganya melalui sarana hukum dengan cara memberi sarana dalam melaksanakan kewajiban kepada masyarakat muslim untuk mengeluarkan dan memberikan sebagian dari rizki dalam bentuk infak dan sadaqoh untuk membiayai program pembangunan dan meningkatkan kesejahteraan masyarakat melalui sebuah mekanisme dan sistem aturan hukum yang berlaku.

Banyak orang yang belum memahami bahwa mengeluarkan zakat dapat mengurangi pajak. Hal ini sesuai dengan UU No. 23 tahun 2011 tentang pengelolaan zakat. Dasar hukumnya terdapat pada pasal 22 dan 23 ayat 1-2. Aturan tersebut berbunyi;

- Pasal 22: Zakat yang dibayarkan oleh muzaki kepada BAZNAS atau LAZ dikurangkan dari penghasilan kena pajak.

- Pasal 23: Baznas atau LAZ wajib memberikan bukti setoran zakat kepada setiap muzaki (pemberi zakat), dan bukti tersebut digunakan sebagai pengurang penghasilan kena pajak.

Tujuan diberlakukan aturan ini adalah agar umat muslim yang hendak mengeluarkan zakat tidak dikenakan double charge atau beban ganda. Selain itu, aturan ini mendorong umat muslim untuk tetap taat beragama dan juga mendorong aspek kemanusiaan.

Sementara itu adanya Undang-Undang Nomor 36 Tahun 2008 Tentang Perubahan keempat atas Undang-Undang Nomor 7 Tahun 1983 Tentang Pajak Penghasilan, dianggap sebagai peraturan yang akan berpotensi terhadap dua kewajiban yang melekat bagi mayoritas masyarakat muslim, sehingga melalui hukum pula diantisipasi kemungkinan double kewajiban tersebut. Dalam kafasitas masyarakat terhadap kewajiban pajak, maka pajak dapat dilihat sebagai sumber 
pendapatan negara yang masih menjadi andalan untuk dijadikan modal pembangunan di Indonesia, sehingga regulasi yang berkaitan dengan pajakpun dinilai cukup memberi nilai terhadap upaya pencapaian hasil yang diharapkan. Undang-undang tentang Pajak Penghasilan Pasal 4 ayat (3), yang tidak termasuk sebagai Objek Pajak adalah :

a. Bantuan sumbangan, termasuk zakat yang diterima oleh badan amil zakat atau lembaga amil zakat yang dibentuk atau disahkan oleh Pemerintah dan para penerima zakat yang berhak; serta harta hibahan yang diterima oleh keluarga sedarah dalam garis keturunan lurus satu derajat, dan oleh badan keagamaan atau badan pendidikan atau badan sosial atau pengusaha kecil termasuk koperasi yang ditetapkan oleh Menteri Keuangan; sepanjang tidak ada hubungan dengan usaha, pekerjaan, kepemilikan, atau penguasaan antara pihak-pihak yang bersangkutan;

b. Warisan;

c. Harta termasuk setoran tunai yang diterima oleh badan sebagaimana dimaksud dalam Pasal 2 ayat (1) huruf b sebagai pengganti saham atau sebagai pengganti penyertaan modal;

d. Penggantian atau imbalan sehubungan dengan pekerjaan atau jasa yang diterima atau diperoleh dalam bentuk natura dan atau kenikmatan dari Wajib Pajak atau Pemerintah;

e. Pembayaran dari perusahaan asuransi kepada orang pribadi sehubungan dengan asuransi kesehatan, asuransi kecelakaan, asuransi jiwa, asuransi dwiguna, dan asuransi beasiswa;

f. Dividen atau bagian laba yang diterima atau diperoleh perseroan terbatas sebagai Wajib Pajak dalam negeri, koperasi, Badan Usaha Milik Negara, atau Badan Usaha Milik Daerah, dari penyertaan modal pada badan usaha yang didirikan dan bertempat kedudukan di Indonesia dengan syarat:

1) Dividen berasal dari cadangan laba yang ditahan; dan

2) Bagi perseroan terbatas, Badan Usaha Milik Negara dan Badan Usaha Milik Daerah yang menerima dividen, kepemilikan saham pada badan yang memberikan dividen paling rendah 25\% (dua puluh lima persen) dari jumlah 
modal yang disetor dan harus mempunyai usaha aktif di luar kepemilikan saham tersebut.

g. Iuran yang diterima atau diperoleh dana pensiun yang pendiriannya telah disahkan oleh Menteri Keuangan, baik yang dibayar oleh pemberi kerja maupun pegawai;

h. Penghasilan dari modal yang ditanamkan oleh dana pension sebagaimana dimaksud pada huruf g, dalam bidang-bidang tertentu yang ditetapkan dengan Keputusan Menteri Keuangan;

i. Bagian laba yang diterima atau diperoleh anggota dari perseroan komanditer yang modalnya tidak terbagi atas saham-saham, persekutuan, perkumpulan, firma, dan kongsi;

j. Bunga obligasi yang diterima atau diperoleh perusahaan reksadana selama 5 (lima) tahun pertama sejak pendirian perusahaan atau pemberian ijin usaha;

k. Penghasilan yang diterima atau diperoleh perusahaan modal ventura berupa bagian laba dari badan pasangan usaha yang didirikan dan menjalankan usaha atau kegiatan di Indonesia, dengan syarat badan pasangan usaha tersebut:

1) Merupakan perusahaan kecil, menengah, atau yang menjalankan kegiatan dalam sektor-sektor usaha yang ditetapkan dengan Keputusan Menteri Keuangan; dan

2) Sahamnya tidak diperdagangkan di bursa efek di Indonesia.

Pada perspektif kewajiban warga negara, maka dengan adanya sarana hukum berupa Undang-Undang Nomor 36 Tahun 2008 Tentang Perubahan keempat atas Undang-Undang Nomor 7 Tahun 1983 Tentang Pajak Penghasilan dan Undang-Undang Nomor 23 Tahun 2011 Tentang Pengelolaan Zakat memberikan dua kewajiban yang sama-sama mempunyai kekuatan hukum berbentuk undang-undang.

Melalui Peraturan Direktur Jenderal Pajak Nomor Per-15/Pj/2012 Tentang Perubahan Peraturan Direktur Jenderal Pajak Nomor Per-33/Pj/2011Tentang Badan/Lembaga Yang Dibentuk Atau Disahkan Oleh Pemerintah Yang Ditetapkan Sebagai Penerima Zakat Atau Sumbangan Keagamaan Yang Sifatnya Wajib Yang 
Dapat Dikurangkan Dari Penghasilan Bruto telah memberi paradigma terhadap pemahaman tentang pajak penghasilan.

Pengurangan dari penghasilan bruto yang dimaksud merupakan pengurangan atas Kontribusi wajib kepada Negara yang terutang oleh orang pribadi atau badan atas setiap tambahan kemampuan ekonomis yang diterima wajib pajak dalam negeri atau luar negeri yang dapat dipakai konsumsi atau menambah kekayaan wajib pajak dengan nama dan bentuk apapun dengan merujuk pada Undang-undang pajak penghasilan sebagaimana telah diubah beberapa kali dan terakhir dengan Undang-Undang Nomor 36 Tahun 2008 yang sifatnya bersih.

Menurut Siti Resmi pajak penghasilan adalah pajak yang dikenakan terhadap subjek pajak atau penghasilan yang diterima atau diperoleh dalam satu tahun pajak.21 Pajak penghasilan sebagaimana menurut Undang-Undang Nomor 36 Tahun 2008, dalam Pasal 4 ayat satu Undang-undang Nomor 36 tahun 2008 disebutkan Penghasilan adalah setiap tambahan kemampuan ekonomis yang diterima wajib pajak yang berasal dari Indonesia maupun dari luar Indonesia yang dapat dipakai konsumsi atau untuk menambah kekayaan wajib pajak yang bersangkutan dengan nama dan dalam bentuk apapun. 


\section{BAB 3 \\ PENUTUP}

\section{A. Kesimpulan}

Berdasarkan tentang pembayaran zakat dan pajak di negara hukum pancasila maka dapat disimpulkan sebagai berikut :

1. Negara hukum Pancasila mengakomodir hukum yang bersumber dari hukum agama mengingat bagi bangsa Indonesia beragama merupakan keharusan dan tidak terdapat tempat bagi masyarakat yang tidak beragama di Indonesia. Terlebih mayoritas bangsa Indonesia beragama Islam, maka negara wajib menjadi fasilitator untuk terwujudkan hukum agama bagi masyarakat muslim.

2. Penghasilan adalah setiap tambahan kemampuan ekonomis yang diterima wajib pajak yang berasal dari Indonesia maupun dari luar Indonesia yang dapat dipakai konsumsi atau untuk menambah kekayaan wajib pajak yang bersangkutan dengan nama dan dalam bentuk apapun.

\section{B. Saran}

1. Untuk meningkatkan peran negara untuk menjadi fasilitator terwujudnya hukum agama di negara Pancasila, maka melalui pemerintah pula diperlukan penegakan sekaligus sosialisasi kepada masyarakat dengan baik regulasi tentang zakat pengurang pajak penghasilan.

2. Untuk meningkatkan kepercayaan masyarakat peraturan perundangundangan yang mengatur setoran masyarakat terhadap negara dan pembayaran zakat kepada lembaga diperlukan usaha konkrit dari pemerintah sebagai wujud amanah dari masyarakat. 


\section{DAFTAR PUSTAKA}

\section{References}

ashari, M. R. (2019). ZAKAT SEBAGAI PENGURANG PAJAK DALAM HUKUM INDONESIA. Retrieved from http://journal.umpalangkaraya.ac.id/index.php/jhm/article/view/881/817

Dr. H. Aden Rosadi, M. (2009). M.Ag. Bandung: Simbiosa Rekatama Media. Diambil kembali dari http://digilib.uinsgd.ac.id/21442/1/Hukum\%20Zakat\%20dan\%20Wakaf.pd f

HAFIDH. (2020, Juni 11). Berita regulasi. Retrieved from Klikpajak by mekari: https://klikpajak.id/blog/zakat-pengurang-pajak/

Hafsah, A. N. (2018). REGULASI ZAKAT SEBAGAI PENGURANG PENGHASILAN KENA PAJAK. Retrieved from http://repositori.uinalauddin.ac.id/13564/1/REGULASI\%20ZAKAT\%20SEBAGAI\%20PEN GURANG\%20PENGHASILAN\%20KENA\%20PAJAK\%20PADA.pdf

Lutfi, M. (2021). KOMPILASI REGULASI ZAKAT DAN PAJAK. Retrieved from https://stai-binamadani.e-journal.id/madanisyariah

mulyana, C. S. (2017). PEMBAYARAN ZAKAT DAN PAJAK DI NEGARA HUKUM PANCASILA. Retrieved from https://ejournal.unisba.ac.id/index.php/syiar_hukum/article/view/2205

pajak, O. (2018, september 20). online pajak. Retrieved from https://www.onlinepajak.com/tentang-pajak/uu-no-36-tahun-2008 